\title{
ERK Inhibitor MK-8353
}

National Cancer Institute

\section{Source}

National Cancer Institute. ERK Inhibitor MK-8353. NCI Thesaurus. Code C104045.

An orally available inhibitor of extracellular signal-regulated kinase (ERK), with potential antineoplastic activity. Upon oral administration, MK-8353 inhibits both ERK phosphorylation and activation of ERK-mediated signal transduction pathways; thereby, preventing ERK-dependent tumor cell proliferation and survival. The mitogen-activated protein kinase (MAPK)/ERK pathway is often upregulated in a variety of tumor cell types and plays a role in tumor cell proliferation, differentiation and survival. 